\title{
Rehber Öğretmenlerin Duygusal Zeka Düzeylerinin İncelenmesi
}

\section{Examining the Emotional Intelligence Levels of Guidance Practitioners}

\section{Soner ALTINKAYNAK* S. Gülfem ÇAKIR ${ }^{* *}$}

Öz: Bu çalışmanın amacı, devlet okullarında rehber öğretmen kadrosunda görev yapan psikolojik danışma ve rehberlik lisans programı mezunları ile diğer lisans programları mezunlarının duygusal zeka düzeyleri arasında anlamlı bir farkın olup olmadı̆̆ını incelemektir. Araştırmaya 2011-2012 eğitim-öğretim yılında Antalya ilinde Milli Eğitim Bakanlığı'na bağlı okullarda rehber öğretmen kadrosunda görev yapan 162 rehber öğretmen katılmıştır. Katılımcıların \%54.9’u kadın ve \%45.1'i erkektir ve yaşları 20 ile 46 arasında değişmektedir. Araştırmada, Bar-On (1997) tarafından geliştirilen ve Türkçe'ye uyarlaması Mumcuoğlu (2002) tarafından yapılan Bar-On Duygusal Zeka Ölçeği kullanılmıştır. Araştırmada PDR lisans mezunu olan ve olmayan rehber öğretmenlerin duygusal zeka alt boyutlarından aldıkları puanlar arasında anlamlı bir farkın olup olmadığı test edilmiştir. Araştırmanın bulguları, devlet okullarında rehber öğretmen kadrosunda görev yapan Psikolojik Danışma ve Rehberlik mezunları ile diğer lisans programları mezunlarının duygusal zeka alt boyutlarındaki (Duygusal Öz-farkındalık, Girişkenlik, Öz Saygı, Öz-Gerçekleştirme, Bağımsızlık, Empati, Sosyal Sorumluluk, Kişilerarası İlişki, Gerçeklik Değerlendirmesi, Esneklik, Problem Çözme, Strese Tolerans, Dürtü Kontrolü, İyimserlik, Mutluluk) düzeyleri arasında psikolojik danışma ve rehberlik lisans mezunları lehine anlamlı bir farklılık olduğunu göstermiştir. Bu sonuçlar, uzmanlık gerektiren bir çalışma alanı olan rehberlik ve psikolojik danışma hizmetlerini yürütecek olan rehber öğretmenlerin atama kriterlerinin önemini vurgular niteliktedir.

Anahtar sözcükler: Mezuniyet Alanı, Duygusal Zeka, Rehberlik Hizmetleri, Rehber Öğretmen

\begin{abstract}
The purpose of this study was to examine whether there is a significant difference between the emotional intelligence levels of guidance practitioners who have a degree in psychological counselling and guidance, and those who have a degree in a major other than psychological counselling and guidance. The study sample comprised 162 guidance practitioners working in state schools in Antalya in the academic year 2011-2012, 54.9\% of the participants were female, $45.1 \%$ of participants were male. The data for this study was collected employing the Bar-On Emotional Quotient Inventory which was developed by Bar-On (1997) and adapted to Turkish by Mumcuoğlu (2002). According to the t-test results, there were significant differences in the emotional intelligence levels between psychological counselling and guidance graduates and the graduates from other programs. Psychological counselling and guidance graduates scored higher in all the subscales of emotional intelligence (emotional self-awareness, assertiveness, self-regard, selfactualization, independence, empathy, social responsibility, interpersonal relationships, reality testing, flexibility, problem solving, stress tolerance, impulse control, optimism, and happiness) than the graduates of other programs. These findings indicate the importance of the appointment criteria in appointing guidance practitioners to guidance and counselling services in schools.
\end{abstract}

Keywords: Graduation Area, Emotional Intelligence, Guidance Services, Guidance Practitioner

\footnotetext{
*Uzm. Psikolojik Danışman, Milli Eğitim Bakanlığı, soneraltinkaynak07@hotmail.com

** Yrd. Doç. Dr., Akdeniz Üniversitesi, Eğitim Fakültesi, Eğitim Bilimleri Bölümü, Antalya. glfmcakir@gmail.com
} 


\section{Giriş}

Günlük yaşantılarda seçimler yapmak, kararlar almak ve çevreye uyum sağlamak yaşamın gereklerindendir. Bireyler problemlerinin birçoğuna kendi başlarına yeterli bir çözüm yolu bulabilirler, ancak bazı problemler karşısında kendilerini çıkmazda hissedip çözüm yolu için farklı bir bireyin yardımına ihtiyaç duyabilirler (Tan 1992). Bu bağlamda özellikle çocuklara ve gençlere gerek rehberlik gerekse psikolojik yardım hizmeti sunma açısından okullarda ve eğitim öğretimin her kademesinde psikolojik danışma ve rehberlik hizmetleri eğitimin ayrılmaz bir parçası haline gelmiştir. Çağdaş eğitim sistemi içerisinde rehberlik ve psikolojik danışma hizmetleri öğretimin tamamlayıcısı niteliğindedir (Yeşilyaprak 2013).

Rehberlik ve psikolojik danışma hizmetleri kapsamı gereği çok karmaşık süreçleri olan ve beceri gerektiren bir hizmet alanıdır (Schmidt 2004). Milli Eğitim Bakanlığı Mesleki Bilgilendirme Sisteminde, Psikolojik Danışma ve Rehberlik programında okumak isteyen bir kimsenin ortalamanın üzerinde bir akademik yeteneğe sahip, sosyal bilimlere, özellikle psikolojiye ilgisi olan ve bu alanda yetişmiş, kişilerarası ilişkilerde başarıl1, diğer insanları dinlemekten hoşlanan, onlara yardım etmeyi seven, dışa dönük, girişken, sabırlı, empatik becerisi yüksek ve sosyal konulara duyarlı bir birey olması beklenmektedir. Adayların genel olarak davranış bilimlerine ilgi duyan, analitik düşünme yeteneğine sahip, kendini geliştirmeye istekli ve ifade yeteneği yüksek bireyler olmaları akademik başarılarında artırıcı bir etken olmaktadır. Adayların ayrıca hoşgörü sahibi, sabırlı, insanlara içten sevgi ve saygı duyan, dinlemesini bilen, kendinden hoşnut, başkalarını oldukları gibi kabul edebilen, dikkatli, ikna kabiliyeti yüksek, geniş görüşlü, güven veren, sosyal bilim ve sosyal yardım ilgisi gelişmiş, düşüncelerini başkalarına açık bir biçimde aktarabilen, sağlıklı bir iletişim ortamı sağlayabilen, dikkatli, işine özen gösteren, mesleğinin sorunları ile ilgilenen ve sorunlara çözüm yolları bulmaya çalışan, kendini geliştirmeye istekli, coşkulu, yaratıcı kimseler olmaları gerekmektedir (Ulusal Meslek Bilgi Sistemi 2012).

Okullarda yürütülen rehberlik hizmetlerinin bir ayağını rehberlik hizmetleri oluştururken diğer ayağını ise psikolojik danışma oluşturmaktadır. Yeşilyaprak'ın da $(2013,11)$ vurguladığı gibi "psikolojik danışma hizmeti, rehberlik hizmetlerinin merkezini oluşturur". Bu hizmetlerin etkili bir şekilde yürütülebilmesi için meslek elemanlarının gerekli alan bilgisi bulunmasının yanı sıra kişisel nitelikler ve beceriler açısından da kendini geliştirmiş olmaları gerekmektedir. Etkili psikolojik danışmanların kişilik özellikleri arasında; güçlü bir kişilik yapısına sahip olmak, kendine saygı duymak ve kendi olmaktan hoşlanmak, kendi gücünü tanımak ve kabul etmek, değişime açık olmak, yaşamlarını biçimlendirebilecek tercihler yapabilmek, kendini yaşama bağlı hissetmek ve yaşama yönelik tercih yapmak, otantik, samimi ve dürüst olmak, ince bir mizah anlayışına sahip olmak, yaptığı yanlışı itiraf etmekten çekinmemek, genellikle içinde bulunduğu anı yaşayabilmek, diğerlerinin mutluluğuyla ilgilenmek ve ilişkilerinde sağlıklı sınırlar oluşturabilmek gelmektedir (Corey 2008).

Duygusal zeka tanımı, alt boyutları, özelliği, kapsamı, becerileri ve içeriği ile bir rehber öğretmende yüksek düzeyde olması gereken niteliklerle örtüşmektedir. İnsan ilişkilerinde duygusal zeka gerekli ve önemli bir beceridir. İçeriği yoğun insan iletişimi ve insanları anlamayı gerektiren mesleklerde duygusal zeka ve becerilerine sahip olmak önemlidir. Duygusal zeka becerisi yüksek olan psikolojik danışmanların, danışanlarının duygusal yönlerini anlamakta daha hazır olduğu, onların sorunlarına odaklanmakta daha başarılı oldukları söylenebilir. İlk zamanlardan bu yana danışmanlar, öncelikle kendi duygusal tepkileri ve problemleriyle başa çıkmaya çalışmaktadır, bunun sonucunda psikolojik danışma eğitimi gören öğrencilere karşısındakinin duygularından kendi duygularını ayırt etmeyi öğretmek, özellikle empatiyle ilgilenmek eğitimleri- 
nin önemli bir öğesidir (Miville, Carlozzi, Gushue, Schara \& Ueda 2006). Duygusal zekayı geliştirebilmek hem uygun kişisel özelliklere sahip olmayı hem de eğitim almayı gerektirmektedir. Duygusal zekayı geliştirmeye dönük eğitimin süresi ile ilgili alanyazında bir fikir birliğine varılmamıştır. Bar-On (1997) beceriler üzerinde kısa süreli eğitimlerle bile fark edilebilir ölçüde değişimlerin gözlenebileceğini belirtirken, Goleman (2000a) ise eğitim süresinin kısa bir zaman diliminden ziyade duygusal zekanın alt boyutları ile ilgili becerileri kişilik özelliklerine dönüştürebilecek uzun zamanı kapsayan bir eğitim sürecinin gerekli olduğunu belirtmektedir.

Rehberlik ve Psikolojik Danışma lisans programında yer alan derslerin içeriklerine bakıldığında özellikle bu derslerde kuramsal bilgilerin yanı sıra uygulamaya dönük becerilerin de geliştirilmesinin hedeflendiği görülmektedir. Diğer alan mezunlarının programları incelendiğinde ise her ne kadar belirli ölçüde benzer olabilecek kuramsal dersler (örn. Psikoloji, Gelişim Psikolojisi vb.) programda yer almasına rağmen, uygulamaya dönük becerileri geliştirebilecek derslerin bulunmadığı görülmektedir. Çünkü her lisans programı kendi meslek alanına yönelik donanımı kazandıracak bir eğitim sunmaktadır. PDR lisans programı eğitiminde de psikolojik danışma ve rehberlik hizmetlerine yönelik kuramsal bilgilerin yanı sıra özellikle dördüncü sinıfta uygulamaya yönelik dersler bulunmaktadır. Bunlardan bir tanesi bireyle psikolojik danışma uygulamasıdır. Bu ders kapsamında öğrencilerin süpervizyon altında temel psikolojik danışma beceri ve tekniklerini kullanarak bireyle psikolojik danışma yapmaları sağlanmaktadır. Diğer bir uygulama dersi olan grupla psikolojik danışma dersinde, grupla psikolojik danışmanın temel kavram ve ilkelerinin yanı sıra öğrencilerin grupla psikolojik danışma uygulamasını deneyimlemelerine olanak tanınmaktadır. Bu nedenle de Rehberlik ve Psikolojik Danışma lisans programının alanda çalışan meslek elemanlarının duygusal zeka becerilerinin arttırılmasını sağlamada daha etkili olacağı düşünülebilir. Yıldırım'ın (1992) duygusal zekanın alt boyutlarından biri olan empatik beceri üzerine yaptığı bir çalışmanın bulguları empatik becerinin eğitimle kazanılabileceğini göstermiştir. Corey’in (2008) belirttiği gibi bir psikolojik danışmanın kullanması gereken en önemli araçlardan biri de bir birey olarak kendisidir. Psikolojik danışmanlığa hazırlanırken, kişilik ve psikoterapi kuramları hakkında bilgi edinmiş, tanılama, çeşitli müdahale yöntemleri ve insan davranışlarının altında yatan dinamikleri öğrenmiş olmak gerekli temeli oluştursa da yardım ilişkisinde etkili bir iletişimi oluşturmak ve sürdürmek için yeterli değildir (Corey 2008).

Ülkemizde psikolojik danışman istihdamını büyük oranda MEB sağlamakla birlikte özel okullar, özel eğitim kurumları ve kamudaki bazı kurumlar da istihdam sağlamaktadır. İstihdam sağlanırken kurumların öne sürdügü öncelikli şart rehber öğretmen ya da psikolojik danışman unvanı için gerekli program olarak Psikolojik Danışma ve Rehberlik (PDR) ya da Eğitimde Psikolojik Hizmetler (EPH) bölümlerinden mezun olmaktır. Ancak MEB rehber öğretmen ataması yaptığı değişik dönemlerde adı geçen programlara farklı programlar ekleyerek Psikoloji, Felsefe, Sosyoloji ve Eğitim Bilimlerine bağlı bazı program mezunlarını da aynı unvanla istihdam etmiştir. Her bir lisans eğitim programının farklı bir hedefi olduğu göz önünde bulundurulduğunda, PDR ya da EPH mezunlarının diğer alan mezunları ile karşılaştırıldığında, mezuniyet sonrasında sahip oldukları nitelikler açısından farklılıklar bulunması beklenir bir durumdur. Bu çalışma kapsamında farklıların gözlenebileceği alanlardan bir tanesinin de duygusal zekayı oluşturan becerilerin olduğu düşünülmektedir. Bu nedenle bu çalışma kapsamında devlet okullarında görev yapan PDR lisans programından mezun olan rehber öğretmenlerin duygusal zeka düzeyleri ile diğer lisans programlarından mezun olup Milli Eğitim Bakanlığı'na bağlı resmi bir okulda görev yapan rehber öğretmenlerin duygusal zeka düzeyleri arasında farkl1lıkların olup olmadığını incelenmiştir. 


\section{Yöntem}

\section{Çalışma Grubu}

Araştırma kapsamında 2011-2012 eğitim öğretim yılında Antalya ilinde Milli Eğitim Bakan1ı̆̆ı'na bağlı resmi okullarda rehber öğretmen kadrosunda görev yapan 518 rehber öğretmenden 162 kişiye ulaş1labilir örnekleme yöntemiyle ulaşılmıştır. Katılımcıların 89'u $(\% 54,9)$ kadın ve 73 'ü $(\% 45,1)$ erkektir ve yaşları 20 ile 46 arasında değişmektedir. Katılımcıların 118'i $(\% 72,8)$ lisans derecelerini PDR ya da Eğitimde Psikolojik Hizmetler bölümünden alırken, 44’ü (\%27,2) lisans derecelerini diğer bölümlerden (Özel Eğitim, Felsefe, EYDP, EPÖ, Sosyoloji, Halk Eğitimi ve Psikoloji) almışlardır.

\section{Veri Toplama Araçları}

Araştırmada, Bar-On (1997) tarafindan geliştirilen ve Türkçe'ye uyarlaması Mumcuoğlu (2002), tarafından yapılan Bar-On Duygusal Zeka Ölçeği ve kişisel bilgi formu kullanılmıştır.

Bar-On Duygusal Zeka Ölçeği (Bar-On EQ-i), Bar-On (1997) tarafından geliştirilmiş olan ve duygusal zekâ boyutlarını ölçen 133 maddelik, 1'den 5'e doğru artan derecelendirme ölçeğine göre yanıtlanan bir kağıt-kalem testidir. On beş duygusal zekâ boyutunun gruplandırıldığ 1 beş ana boyutu bulunmaktadır: Kişilerarası, Kişiye özgü, Stres Yönetimi / Denetimi, Uyumluluk ve Genel Mizaç. Her ölçek kendi içinde iki ila beş alt ölçeğe ayrılmıştır. Kişiye özgü boyutu beş alt ölçekten oluşmaktadır: Duygusal Öz-Farkındalık (7, 9, 23, 35, 52, 63, 88 ve 116), Girişkenlik (22, 37, 67, 82, 96, 111 ve 126), Öz Sayg1 (11, 24, 40, 56, 70, 85, 100, 114 ve 129), ÖzGerçekleştirme (6, 21, 36, 51, 66, 81, 95, 110 ve 125), ve Bağımsızlık (3, 19, 32, 48, 92, 107 ve 121). Kişilerarası boyutu üç alt ölçekten oluşmaktadır: Empati (18, 44, 55, 61, 72, 98, 119 ve 124), Sosyal Sorumluluk (16, 30, 46, 61, 72, 76, 90, 98, 104 ve 119) ve Kişilerarası İlişkiler (10, 23, 31, 39, 55, 62, 69, 84, 99, 113 ve 128). Uyumluluk boyutu üç alt ölçekten oluşmaktadır: Gerçeklik Değerlendirmesi ( 8, 35, 38, 53, 68, 83, 88, 97, 112 ve 127), Esneklik (14, 28, 43, 59, 74, 87, 103 ve 131) ve Problem Çözme (1, 15, 29, 45, 60, 75, 89 ve 118). Dördüncü ölçek olan Stres Denetimi boyutu iki alt ölçekten oluşmaktadır: Stres Tolerasyonu (4, 20, 33, 49, 64, 78, 93, 108 ve 122) ve Dürtü Kontrolü (13, 27, 42, 58, 73, 86, 102, 117 ve 130). Beşinci boyut olan Genel Mizaç ölçeği iki alt ölçek ten oluşmaktadır: Mutluluk (2, 17, 31, 47, 62, 77, 91, 105 ve 120) ve İyimserlik: (11, 20, 26, 54, 80, 106, 108 ve 132).

Ölçeğin Türk kültürüne uyarlama çalışması Mumcuoğlu (2002) tarafından yapılmıştır. Ölçeğin dil eşdeğerliği çalışmasında ölçeğin İngilizce ve Türkçe formları bir çalışma grubuna ( $N=$ 33) uygulanmış ve ölçeğin 15 alt boyutu için iki farklı formundan elde edilen puanların korelasyon katsayılarının .71 ile .95 arasında değiştiği rapor edilmiştir. Ölçeğin Türkçe formunun yap1 geçerliliğini test etmek için madde analizi ve kriter geçerliliği kullanılmıştır. Madde analizinde madde ayırt ediciliği analizi yapılmış ve madde-toplam puan korelasyon katsayıları hesaplanmıştır. Madde ayırt ediciliği analizi sonuçlarına göre, testin içerdiği tüm boyutların ve bu boyutların tüm maddelerinin anlamlı derecede ayırt ediciliğe sahip olduğu ifade edilmiştir. Ölçeğin güvenirlik çalışmasında ise iç tutarlılık katsayıları ve test-tekrar test katsayıları hesaplanmıştır. Bu sonuçlara göre 15 alt ölçek için iç güvenirlik katsayıları .48 ile .84 arasında değişirken, test-tekrar test katsayıları .71 ile .93 arasında değişmektedir. Ölçeğin bu çalışma kapsamında ele edilen iç tutarlılık katsayıları Tablo 1'de sunulmaktadır. 
Tablo 1. Ölçeğin İç Tutarlılık Katsayıları

\begin{tabular}{|l|l|}
\hline Alt boyutlar & Güvenirlik katsayıları \\
\hline Duygusal Öz-farkındalık & .93 \\
\hline Girişkenlik & .89 \\
\hline Öz Saygı & .94 \\
\hline Öz Gerçekleştirme & .93 \\
\hline Bağımsızlık & .84 \\
\hline Empati & .61 \\
\hline Kişilerarası İlişki & .94 \\
\hline Sosyal Sorumluluk & .73 \\
\hline Problem Çözme & .92 \\
\hline Gerçeklik Değerlendirmesi & .86 \\
\hline Esneklik & .88 \\
\hline Strese Tolerans & .96 \\
\hline Dürtü Kontrolü & .92 \\
\hline Mutluluk & .91 \\
\hline İimserlik & .93 \\
\hline
\end{tabular}

\section{Bulgular}

Bu bölümde, Milli Eğitim Bakanlığı'na bağl1 resmi okullarda görev yapan rehber öğretmenlerin, duygusal zekanın alt boyutlarından aldıkları puanlarda mezun oldukları lisans programlarına göre farklılık olup olmadığına ilişkin analiz sonuçları sunulmuştur. Katılımcıların duygusal özfarkındalık, girişkenlik, öz saygı, öz-gerçekleştirme, bağımsızlık, empati, sosyal sorumluluk, kişilerarası ilişkiler, gerçeklik değerlendirmesi, esneklik, problem çözme, strese tolerans, dürtü kontrolü, iyimserlik ve mutluluk düzeylerinde mezun oldukları alanlara göre farklılık olup olmadığını incelemek amacıyla on beş ayrı t-testi yapılmıştır. Analiz öncesinde dağılımın normalliği için merkezi eğilim ölçümleri, basıklık katsayısı, çarpıklık katsayısı ve histogramlar incelendiğinde her bir dağılımın normale yakın olduğu görülmüştür. Analiz sonuçlarının yorumlanmasında etki büyüklügünü belirlemek için $\mathrm{t}$ değerlerinin karşılık geldiği korelasyon katsayısı (r) hesaplanmıştır. Korelasyon katsayısı değerlerine göre $r>.5$ ise yüksek bir etki büyüklüğünün bulunduğunu göstermektedir (Field 2005).

Araştırmada elde edilen bulgular şu şekilde özetlenebilir (Tablo 2):

1. Araştırmada kişisel farkındalık boyutunu oluşturan farkındalık, girişkenlik, öz saygı, özgerçekleştirim ve bağımsızlık alt boyutları açısından PDR programından mezun olup olmamaya bağlı olarak anlamlı bir farklılığın olup olmadığını incelemek için yapılan $t$-testi sonuçlarına göre PDR mezunu rehber öğretmenlerin tüm alt boyutlardaki puanlarının diğer alan mezunlarından daha yüksek olduğu bulunmuştur.

Tablo 2. Mezuniyet Alanlarına Göre Duygusal Zeka Düzeyleri

\begin{tabular}{|c|c|c|c|c|c|c|c|}
\hline & $\begin{array}{c}\text { Mezuniyet } \\
\text { Alanı }\end{array}$ & $\mathbf{n}$ & $\bar{x}$ & Ss & Sd & $\boldsymbol{t}$ & $\boldsymbol{p}$ \\
\hline \multirow{2}{*}{$\begin{array}{c}\text { Duygusal Öz- } \\
\text { farkındalık }\end{array}$} & PDR & 118 & 37.50 & 2.31 & 160 & 30.51 & .000 \\
\cline { 2 - 8 } & Diğer & 44 & 24.55 & 2.65 & 68.85 & & \\
\hline \multirow{2}{*}{ Girişkenlik } & PDR & 118 & 31.93 & 2.17 & 160 & 22.04 & .000 \\
\cline { 2 - 8 } & Diğer & 44 & 20.77 & 3.09 & 59.52 & & \\
\hline Öz Saygı & PDR & 118 & 42.47 & 2.32 & 160 & 22.50 & .000 \\
\hline
\end{tabular}




\begin{tabular}{|c|c|c|c|c|c|c|c|}
\hline & Diğer & 44 & 29.66 & 3.50 & 57.59 & & \\
\hline \multirow{2}{*}{$\begin{array}{c}\text { Öz- } \\
\text { gerçekleştirme }\end{array}$} & PDR & 118 & 42.07 & 2.29 & 160 & 32.85 & .000 \\
\hline & Diğer & 44 & 28.16 & 2.66 & 68.25 & & \\
\hline \multirow{2}{*}{ Bağımsızlık } & PDR & 118 & 32.30 & 2.24 & 160 & 25.56 & .000 \\
\hline & Diğer & 44 & 23.77 & 1.74 & 99.03 & & \\
\hline \multirow{2}{*}{ Empati } & PDR & 118 & 38.21 & 4.18 & 160 & 14.28 & .000 \\
\hline & Diğer & 44 & 28.52 & 2.73 & 117.70 & & \\
\hline \multirow{2}{*}{$\begin{array}{c}\text { Sosyal } \\
\text { Sorumluluk }\end{array}$} & PDR & 118 & 46.95 & 4.20 & 160 & 19.15 & .000 \\
\hline & Diğer & 44 & 33.73 & 2.99 & 107.90 & & \\
\hline \multirow{2}{*}{$\begin{array}{l}\text { Kişilerarası } \\
\text { İlişkiler }\end{array}$} & PDR & 118 & 51.50 & 2.94 & 160 & 33.90 & .000 \\
\hline & Diğer & 44 & 33.95 & 2.89 & 78.31 & & \\
\hline \multirow{2}{*}{$\begin{array}{c}\text { Gerçeklik } \\
\text { Değerlendirmesi }\end{array}$} & PDR & 118 & 43.69 & 2.35 & 160 & 25.49 & .000 \\
\hline & Diğer & 44 & 32.14 & 3.09 & 62.51 & & \\
\hline \multirow{2}{*}{ Esneklik } & PDR & 118 & 36.25 & 2.31 & 160 & 18.81 & .000 \\
\hline & Diğer & 44 & 25.80 & 2.65 & 58.38 & & \\
\hline \multirow{2}{*}{ Problem Çözme } & PDR & 118 & 37.38 & 2.15 & 160 & 31.56 & .000 \\
\hline & Diğer & 44 & 25.93 & 2.02 & 81.86 & & \\
\hline \multirow{2}{*}{ Strese Tolerans } & PDR & 118 & 41.86 & 2.55 & 160 & 24.17 & .000 \\
\hline & Diğer & 44 & 26.02 & 4.06 & 56.11 & & \\
\hline \multirow{2}{*}{ Dürtü Kontrolü } & PDR & 118 & 41.71 & 2.56 & 160 & 24.66 & .000 \\
\hline & Diğer & 44 & 30.23 & 2.83 & 70.93 & & \\
\hline \multirow{2}{*}{ İyimserlik } & PDR & 118 & 36.98 & 1.78 & 160 & 24.92 & .000 \\
\hline & Diğer & 44 & 24.36 & 3.18 & 53.42 & & \\
\hline \multirow{2}{*}{ Mutluluk } & PDR & 118 & 41.30 & 2.74 & 160 & 27.58 & .000 \\
\hline & Diğer & 44 & 27.48 & 3.09 & 69.63 & & \\
\hline
\end{tabular}

2. Araştırmada rehber öğretmenlerin kişiler arası ilişkiler boyutunu oluşturan empati, kişilerarası ilişkiler ve sosyal sorumluluk açısından PDR programından mezunu olup olmamaya bağlı olarak anlamlı bir farklılığın olup olmadığını incelemek için yapılan $t$-testi sonuçlarına göre PDR mezunu rehber öğretmenlerin üç alt boyuttaki puanlarının da diğer alan mezunlarından daha yüksek olduğu bulunmuştur.

3. Araştırmada rehber öğretmenlerin şartlara ve çevreye uyum boyutunu oluşturan gerçeklik değerlendirmesi, esneklik ve problem çözme açısından PDR programından mezun olup olmamaya bağlı olarak anlamlı bir farklılığın olup olmadığını incelemek için yapılan $t$-testi sonuçlarına göre PDR mezunu rehber öğretmenlerin her üç alt boyuttaki puanlarının da diğer alan mezunlarından daha yüksek olduğu bulunmuştur.

4. Araştırmada rehber öğretmenlerin stres yönetimi boyutunu oluşturan stres tolerasyonu ve dürtü kontrolü açısından PDR programından mezun olup olmamaya bağlı olarak anlamlı bir farklılığın olup olmadığını incelemek için yapılan $t$-testi sonuçlarına göre PDR mezunu rehber öğretmenlerin her iki alt boyuttaki puanlarının da diğer alan mezunlarından daha yüksek olduğu bulunmuştur.

5. Araştırmada rehber öğretmenlerin genel ruh hali boyutunu oluşturan mutluluk ve iyimserlik açısından PDR programından mezun olup olmamaya bağlı olarak anlamlı bir farklılığın olup olmadığını incelemek için tapılan t-testi sonuçlarına göre PDR mezunu rehber öğretmenlerin her iki boyuttaki puanlarının da diğer alan mezunlarından daha yüksek olduğu bulunmuştur. 


\section{Sonuç, Tartışma ve Öneriler}

Bu çalışmada, MEB'e bağlı devlet okullarında görev yapan rehberlik ve psikolojik danışma lisans programı mezunu rehber öğretmenlerin duygusal zeka düzeyleri ile diğer alan mezunu rehber öğretmenlerin duygusal zeka düzeyleri arasında anlamlı bir farkın bulunup bulunmadığ araştırılmıştır. Araştırma bulguları 2011-2012 yıllarında Antalya ilinde devlet okullarında görev yapan rehber öğretmenlerden elde edilen bulgulara dayanmakta ve araştırmanın değişkenleri Bar-On Duygusal Zeka ölçeğinin ölçtüğü niteliklerle sınırlıdır. Araştırmada, duygusal zeka düzeyleri kişisel farkındalık, kişiler arası ilişkiler, şartlara ve çevreye uyum, stres yönetimi ve genel ruh hali boyutlarını oluşturan 15 alt boyut açısından incelenmiştir. Araştırmada elde edilen bulgular bu beş ana boyutun başlığı altında gruplandırılmıştır ve tartış1lmıştır.

Araştırmada kişisel farkındalık boyutunu oluşturan farkındalık, girişkenlik, öz saygı, özgerçekleştirme ve bağımsızlık alt boyutları açısından PDR mezunu rehber öğretmenlerin tüm alt boyutlardaki düzeylerinin diğer alan mezunlarından daha yüksek olduğu bulunmuştur. Alanyazında bu çalışmada elde edilen bulgularla doğrudan karşılaştırılabilecek bulgu bulunmamakla birlikte, benzer çalışmalara ait bulgular bulunmaktadır. Bunlardan bir tanesi Yiyit’in (2001) Eğitimde Psikolojik Hizmetler bölümü mezunları ile Psikoloji bölümü mezunlarının özel eğitime ilişkin öz-yeterlilik algıları arasındaki farkı incelediği çalışmasıdır. Araştırma sonucunda, EPH lisans mezunları lehine anlamlı bir fark ortaya çıkmıştır ve bu farkın ortaya çıkmasının en önemli etkenlerinden birinin EPH lisans mezunlarının okul danışmanlığı temelli eğitimleri olduğu düşünülmektedir. Mevcut çalışmanın bulgularında da PDR mezunu rehber öğretmenlerin farkındalık düzeylerinin daha yüksek bulunmasının lisans düzeyindeki eğitim programı ve ders içeriği ile ilgili olduğu düşünülebilir.

Diğer yandan, Özgün'ün (2007) yaptığı çalışmada mezuniyet alanlarına göre rehber öğretmenlerin öz-yeterlilik düzeyleri incelenmiş ve mezuniyet alanına göre rehber öğretmenlerin özyeterlilik düzeylerinde bir farklılık bulunmamıştır. Bu çalışma bulguları mevcut çalışma bulguları ile örtüşmemektedir. Farkın çıkmamasının altında yatan nedenlerden bir tanesi alan dışı lisans mezunları ile PDR lisans mezunlarının psikolojik danışma ve görüşme kavramlarına ilişkin bilgi düzeyleri ile ilgili olabilir. Alan dışı rehber öğretmenler psikolojik danışma ile görüşmeyi birbirine eşdeğer süreçler olarak değerlendirip, bunun bir sonucu olarak da psikolojik danışma uygulaması ile ilgili öz-yeterliliklerini yüksek olarak algılamış olabilirler. Bu nedenle psikolojik danışma becerilerinin yeterlilik düzeylerinin incelendiği çalışmalarda becerilerin gözlem yoluyla değerlendirilmesinin yapılmasının daha sağlıklı olacağı düşünülmektedir (Aksoy \& Diken 2009). Bu görüşü destekleyen bir çalışmada da Watson (1992) din öğrenimi üzerine eğitim alan yüksek lisans öğrencileri ile Psikolojik Danışma yüksek lisans öğrencilerinin öz-yeterlilik algılarını incelemiş ve öz-yeterlilik algılarında bir fark bulmamıştır. Ancak aynı grupta video çekimi yapılarak değerlendirilen analizde psikolojik danışma öğrencilerinin danışma becerilerini kullanma ve uygulamada daha yüksek beceri sahibi olduğu bulgusunu elde etmiştir.

Goleman'ın da (2000b) belirttiği gibi kişisel farkındalığı yüksek bireyler, kendisini iyi tanır, kendisini ne aşırı derecede eleştirirler ne de aşırı derecede yüceltirler. Bir diğer deyişle kendilerini gerçekçi bir gözle algılarlar. Bu durum sosyal yaşamda başarıyı etkileyen en önemli etkenlerden biridir (Goleman 2000b). Kişisel farkındalık becerisine sahip olan bireyler, kendi potansiyelini görebildiği ve yetenekleri konusunda doğru bir bilgiye sahip olduğu için özgüvenini artıracak ve kendi değerini daha fazla bilebilecektir (Şirin 2007). Diğer yandan benlik bilinci zayıf bireyler ise bazı değerlerini çiğneyerek, içsel karışıklıklar yaşamaya yol açacak kararlar almaya yatkındır. Benlik bilinci yüksek bireyler ise değer yargılarıyla uyumlu kararlar 
alabilmekte ve enerjilerini kullanabilecekleri işlere yönelebilmektedirler. Duygularının farkında olan ve duygularını düzenleyebilen bireyler daha sağlıklı kişilik yapısına sahiptirler (Weisinger 1998 akt. Yerli 2009). Eğitim kurumlarında rehber öğretmen olarak çalışan meslek elemanlarının kendine değer veren, kendi yeteneklerinin ve yeterliliklerinin farkında olan, özgüveni yüksek kişiler olması yapılan mesleğin gerekliliklerindendir.

Araştırmada rehber öğretmenlerin kişilerarası ilişkiler boyutunu oluşturan empati, kişilerarası ilişkiler ve sosyal sorumluluk açısından PDR mezunu rehber öğretmenlerin üç alt boyuttaki düzeylerinin de diğer alan mezunlarından daha yüksek olduğu bulunmuştur. Çalışmada elde edilen empati ile ilgili bulgu alanyazında bulunan az sayıdaki çalışma bulguları ile örtüşmektedir. Örneğin, Alper'in (2007) yaptığı çalışmada rehber öğretmenler ile sınıf öğretmenlerinin empati düzeyi karşılaştırılmış ve rehber öğretmenler lehine anlamlı bir fark ortaya çıkmıştır. Eğitim fakültesinin farklı bölümlerinde okuyan öğrencilerin bölümlerine göre eleştirel düşünme ve empatik eğilimlerinin incelendiği başka bir çalışmada PDR öğrencilerinin en yüksek empatik eğilim puan ortalamasına sahip oldukları bulunmuştur (Ekinci 2009). Yine Yıldırım'ın (1992) yaptığı bir araştırmada PDR lisans programı 1. sınıf öğrencilerinin empatik eğilim düzeylerinin EÖD, EPÖ ve EYD lisans programındaki 1. sınıf öğrencilerine göre, PDR 4. sınıf öğrencilerinin, Psikoloji 4. sınıf öğrencilerine göre anlamlı derecede yüksek olduğuna dair bulgular elde etmiştir. Araştırmacı empatik eğilimlerin eğitimle kazanılabileceği ve PDR programlarının daha etkin olduğu sonucuna varmıştır. Buna da gerekçe olarak PDR 3. ve 4. sınıf derslerinin genelde uygulamaya dayanması olduğunu belirtmiştir.

Kendini bir başkasının yerine koyamayan kişilerin, karşısındakini anlaması mümkün değildir. Karşısındaki kiş için neyin önemli olduğunu anlayabilmek için empati yapabilmek esastır. Empati yapabilen bireyler karşısındaki insanın tepkilerinin sebebini gerçekçi olarak sezinleyebilir, sorunlarını ve endişelerini anlayabilir (Goleman 2000a) ve buna uygun tepkiler verebilir. Görüldüğü üzere eğitim kurumlarında çalışan meslek elemanlarının psikolojik danışma, bireysel görüşme, grup danışmanlığ 1 gibi rehberlik hizmetlerinin en önemli görevlerini gerçekleştirebilmesi için kişilerarası ilişkiler boyutu ve alt boyutlarına ait becerilere mutlaka sahip olması gerekmektedir.

Araştırmada rehber öğretmenlerin şartlara ve çevreye uyum boyutunu oluşturan gerçeklik değerlendirmesi, esneklik ve problem çözme PDR mezunu rehber öğretmenlerin her üç alt boyuttaki düzeylerinin de diğer alan mezunlarından daha yüksek olduğu bulunmuştur. Sav'ın (2007) yaptığı araştırmada da, PDR mezunu rehber öğretmenlerin kişilik özelikleri alt ölçeklerinden kişisel uyum, duygusal kararlılık, nevrotik eğilimler, psikotik belirtiler puanlarının Psikoloji mezunu rehber öğretmenlerin puanlarından anlamlı düzeyde yüksek olduğu görülmüştür.

Uyum yeteneği yüksek bireyler, sabit fikirli değildir yeni durumlara daha çabuk uyum sağlayabilirler ve olaylara geniş açıdan bakabilirler. Sürekli ve hızla değişen durumlara kolay uyum sağlayıp değişimlerle başa çıkabilirler (Goleman 2000a). Eğitim kurumlarında görev yapan rehber öğretmenlerin karşılaştıkları durumlardan birisi de eğitim sisteminin sürekli değişmesi, değişen öğrenci özellikleri ile birlikte ilgilenilen sorunların çeşitlilik göstermesi, çalışılan personel ve yöneticilerin değişmesidir. Bu durumlara kolay uyum sağlayabilme ve bu durumlara yönelik davranışlar ve stratejiler geliştirebilme meslek elemanlarında bulunması gereken önemli bir beceridir.

Araştırmada rehber öğretmenlerin stres yönetimi boyutunu oluşturan stres tolerasyonu ve dürtü kontrolü PDR mezunu rehber öğretmenlerin her iki alt boyuttaki düzeylerinin de diğer alan mezunlarından daha yüksek olduğu bulunmuştur. Bulut (2007) tarafından 141 okulun psikolojik danışmanı üzerinde yapılan bir çalışmada üniversitede aldıkları eğitimi yeterli olarak 
algılayan psikolojik danışmanların problem çözme ve yaşam doyumu düzeyleri yeterli olarak algılamayanlara göre daha yüksek bulunmuştur. Mevcut çalışmada elde edilen bulgu da üniversite düzeyindeki eğitimin psikolojik danışmanın sahip olacağı beceriler üzerindeki etkisini göstermesi açısından Bulut'un (2007) çalışmasında elde ettiği bulguya ek bir katkı sağlamaktadır. Eğitim kurumlarında görev yapan rehber öğretmenler çalıştıkları ortam gereği ve mesleki görevleri gereği stresli ve sıkıntılı bir ortam içerisinde yer almaktadırlar. Bu durumlarda stres yönetimi önemli ve gerekli bir beceri olarak karşımıza çıkmaktadır.

Araştırmada rehber öğretmenlerin genel ruh hali boyutunu oluşturan mutluluk ve iyimserlik PDR mezunu rehber öğretmenlerin her iki boyuttaki düzeylerinin de diğer alan mezunlarından daha yüksek olduğu bulunmuştur. Genel ruh hali olarak iyimser bir tutum içerisinde olmak hayattaki başarıları etkilemektedir (Maboçoğlu 2006). İyimser insanlar başarısızlığı geçerli bir nedene bağlar ve bu durumun değiştirilebilir olacağına inanır, bunun için çaba gösterir, başarılı olabilmek için denemelere devam eder. Umutsuzluğa kapılmaz, karamsar davranmaz. Genel ruh hali olarak iyimser olmayan ve mutlu hissetmeyen kişiler, başarısızlığın nedenini değiştiremeyeceklerini düşünürler (Goleman, 2000a).

Eğitim kurumlarında görev yapan rehber öğretmenlerin iyimserlik ve mutluluk becerilerine sahip olmaları yukarıda da belirtildiği gibi gerekli bir beceridir. Çünkü rehber öğretmenlerin hem psikolojik danışma hem de rehberlik faaliyetlerinde olumlu ve yapıcı bir tutum içerisinde olmaları beklenmektedir. Rehber öğretmenlik görevini yapan meslek elemanlarının da yaptıkları işten doyum almaları mesleğin gerektirdiği görevlerini başarıyla sürdürebilmeleri için önemlidir. Bunları yaparken de belli becerilere ve niteliklere sahip olmaları gerekmektedir. Çünkü rehberlik faaliyetleri eğitimde çok önemli bir yer teşkil etmektedir. Bu nitelikler de büyük oranda uzun süreli eğitimle kazanılmaktadır. Yapılan birçok araştırmada iş hayatında duygusal zekası yüksek bireylerin daha başarılı olduğuna yönelik sonuçlar mevcuttur. Duygusal zekanın eğitim ile geliştirilebildiği ve bu eğitimin bireyin kendine has zeka düzeyi ölçüsünde, sosyal hayatta becerilerini geliştirme konusunda katkı yaptığı bilinmektedir. Bu sebeple eğitimde zekanın bir yönünü değil, farklı boyutlarını geliştirme yönünde çalışma yapılmalıdır (Yeşilyaprak 2001). Yine Goleman (2000a), duygusal zekanın gelişiminde eğitimin önemine değinirken duygusal yönden öğrencilerin eğitimlerinin şansa bırakıldığını, kalbi ve aklı birleştirerek nasıl eğitilebileceğine dair bir vizyona ihtiyaç duyulduğunu, okullardaki eğitimin öz bilinç, öz denetim, empati, problem çözme, kişilerarası ilişkiler gibi insani becerileri kapsaması gerektiğini belirtmiştir.

Mevcut araştırmanın bulguları genel olarak ele alındığında, PDR programından mezun olan rehber öğretmenlerin duygusal zekalarının diğer alan mezunlarından daha yüksek olduğu görülmektedir. Duygusal zeka rehberlik ve psikolojik danışma hizmetlerinin etkili yürütülebilmesi açısından önemli bir beceri grubudur ve çalışmanın bulgularının gösterdiği gibi PDR program içeriği duygusal zekayı geliştirme açısından belirli bir etkiye sahiptir. Aslan (2003) yaptığı araştırmada alandan ve alan dışından olan rehber öğretmenlerin mesleki etkinliklere ilişkin görüşlerinin karşılaştırılmasında iki alan (oryantasyon, çevre ve veli) dışında diğer sekiz kategoride (rehberlik ve psikolojik danışma programı geliştirme ve uygulama, psikolojik danışma, öğrencileri tanıma, bilgi toplama ve yayma, yerleştirme, araştırma ve değerlendirme, yönetici ve öğretmenlerle konsültasyon yapma) alandan rehber öğretmenlerin ortalamaları, diğer bölüm mezunu rehber öğretmenlerden yüksek olduğu bulgusunu elde etmiştir. Araştırmac1 rehberlik ve psikolojik danışma programı geliştirme ve uygulama, psikolojik danışma, öğrencileri tanıma, bilgi toplama ve yayma, yerleştirme ve değerlendirme, yönetici ve öğretmenlerle konsültasyon yapma ile ilgili hizmet alanlarında Psikolojik Danışma ve Rehberlik 
mezunu rehber öğretmenlerin ortalamalarının yüksek çıkmasının nedenini, sahip olunan eğitim alt yapısıyla psikolojik danışma ve rehberlik alanındaki temel mesleki etkinlikleri gereği gibi yerine getirmelerine dayandırmıştır. Yine araştırmacı bir başka neden olarak alan dışından rehber öğretmenlerin kısa süreli bir hizmetiçi eğitim sonucunda sahip oldukları psikolojik danışma ve rehberlik alanının bilgisiyle hizmetleri yerine getirme konusunda kendilerini yeterli görmediklerini belirtmiştir. Mevcut araştırmanın bulguları, Aslan'ın çalışmasında elde ettiği farkın sebeplerini açıklama yönünde bilgi verici niteliktedir. Ancak duygusal zeka düzeyinin rehber öğretmenlerin sundukları hizmetlerin etkililiğini nasıl etkilediği ile ilgili daha fazla araştırmaya ihtiyaç vardır.

Mevcut araştırmanın bulguları genel olarak ele alındığında, PDR programından mezun olan rehber öğretmenlerin duygusal zekalarının diğer alan mezunlarından daha yüksek olduğu görülmektedir. Okullarda psikolojik danışma ve rehberlik hizmetlerini sunma görevini üstlenen uzmanların sahip olması gereken nitelikler birçok alan uzmanı tarafindan vurgulanmıştır (örneğin Kurt 2007; Corey 2008). Duygusal zeka da rehberlik ve psikolojik danışma hizmetlerinin etkili yürütülebilmesi açısından önemli bir beceri grubudur (Martin, Easton, Wilson, Takemoto \& Sullivan 2004; Easton, Martin \& Wilson 2008) ve çalışmanın bulgularının gösterdiği gibi PDR program içeriği duygusal zekayı geliştirme açısından belirli bir etkiye sahiptir. Bu nedenle bu çalışmanın bulguları, okullarda uzmanlık alanı gerektiren bir göreve o alanda yeterli bilgi ve beceri düzeyine sahip uzmanları atamanın önemini bir kez daha vurgular niteliktedir. Duygusal zeka alanındaki çalışmalar duygusal zekanın eğitimle geliştirilebildiğini göstermektedir. Sonraki çalışmalarda halihazırda atanmış bulunan alandışı rehber öğretmenlere yönelik duygusal zeka eğitim programları geliştirilebilir ve bu programların etkililiği incelenebilir. Bunun yanı sıra, PDR lisans öğrencileri ve farklı alan lisans öğrencilerinin duygusal zeka düzeylerini geliştirmeye yönelik araştırmalar yapılabilir. Duygusal zeka becerileri psikolojik danışmada, danışmanda bulunması gereken özellikleri de kapsayan becerilerdendir. Aynı zamanda PDR mezunu olan rehber öğretmenlerin duygusal zeka düzeyleri farklı değişkenler açısından da incelenebilir. Son olarak, bu araştırmaya benzer bir araştırmanın Türkiye genelinden seçilecek alandan ve alandışı rehber öğretmenleri kapsayacak daha geniş bir çalışma grubu ile yapılması önerilebilir.

\section{KAYNAKÇA}

Aksoy V. \& Diken İ. H. (2009). "Rehber öğretmenlerin özel eğitimde psikolojik danışma ve rehberliğe ilişkin öz yeterlik algılarının incelenmesi”. Ankara Üniversitesi Eğitim Bilimleri Fakültesi, Özel Eğitim Dergisi 10/1 (2009) 29-37.

Alper D. (2007). Psikolojik Danışmanlar ve Sinıf Öğretmenlerinin Duygusal Zeka Düzeyleri-İletişim ve Empati Becerilerinin Karşılaş̧tırılması. Yüksek Lisans Tezi. Dokuz Eylül Üniversitesi, İzmir 2007.

Aslan S. (2003). Ankara İli Ortä̈ğretim Kurumlarında Çalışan Alandan ve Alandlşından Rehber Öğretmenlerin Mesleki Etkinliklerine İlişkin Görüşleri ve Sorunları. Yayınlanmamış Yüksek Lisans Tezi. Hacettepe Üniversitesi, Ankara 2003.

Bar-On R. (1997). Development of the Bar-On EQ-i: a measure of emotional and social intelligence. Amerikan Psikologlar Birliği (105. Yıl Toplantısı Sunumu). Chicago 1997.

Bulut N. (2007). "Okul psikolojik Danışmanlarının Yaşam Doyumu, Stresle Başa Çıkma Stratejileri İle Olumsuz Otomatik Düşünceleri Arasındaki İlişkiler”. Türk Psikolojik Danışma ve Rehberlik Dergisi 3/27 (2007) 1-13.

Corey G. (2008). Psikolojik Danışma, Psikoterapi Kuram ve Uygulamaları. Çev. Tuncay Ergene. Ankara 2008.

Easton C., Martin W. E. \& Wilson S. (2008). "Emotional Intelligence and Implications for Counseling 
Self-Efficacy: Phase II”. Counselor Education and Supervision 47 (2008) 218-222.

Ekinci Ö. (2009). Öğretmen Adaylarının Empatik ve Eleştirel Düşünme Eğilimlerinin İncelenmesi. Yayınlanmamış Yüksek Lisans Tezi. Çukurova Üniversitesi, Adana 2009.

Field A. (2005). Discovering Statistics Using SPSS. London 2005.

Goleman D. (2000a). Duygusal Zekâ. Çev. Banu Seçkin Yüksel. İstanbul 2000.

Goleman D. (2000b). İs Başında Duygusal Zeka. Çev. Handan Balkara Çevikus. İstanbul 2000.

Kurt G. (2007). On Dokuz Mayıs Üniversitesi Rehberlik ve Psikolojik Danışma Bölümü Öğrencilerine Verilen Duygusal Zeka Düşünme Becerileri Eğitiminin Empatik Beceri Düzeylerine Etkisi. Yayımlanmamış Yüksek Lisans Tezi. On Dokuz Mayıs Üniversitesi, Samsun 2007.

Maboçoğlu F. (2006). Duygusal Zeka ve Duygusal Zekanın Gelişimine Katkıda Bulunan Etkenler. Yayınlanmamış Yüksek Lisans Tezi. Ankara Üniversitesi, Ankara 2006.

Martin W. E., Easton C., Wilson S., Takemoto M. \& Sullivan S. (2004). "Salience of Emotional Intelligence As a Core Characteristic of Beng a Counselor”. Counselor Education \& Supervision 44 (2004) 18-30.

Miville M. L., Carlozzi A. F., Gushue G. V., Schara S. L. \& Ueda M. (2006). "Mental Health Counselor Qualities for a Diverse Clientele: Linking Empathy, Universal Diverse Orientation and Emotional Intelligence”. Journal of Mental Health Counseling 28 (2006) 151-165.

Mumcuoğlu Ö. (2002). Bar-On Duygusal Zeka Testi (Bar-On Emotional Quotient Inventory- Bar-On EQi)'nin Türkçe Dilsel Eşdeğerlik, Güvenirlik ve Geçerlik Çalışması. Yayınlanmamış Yüksek Lisans Tezi. Marmara Üniversitesi Eğitim Bilimleri Enstitüsü, İstanbul 2002.

Sav İ. (2007). Psikolojik Danışman Rehber Öğretmenlerin Kişilik Özellikleri ile Stresle Başa Çıkma Stratejileri Arasındaki İlişkinin İncelenmesi. Yayınlanmamış Yüksek Lisans Tezi. Dokuz Eylül Üniversitesi, İzmir 2007.

Schmidt J. J. (2004). Counseling In Schools: Essential Services and Comprehensive Programs. Boston 2004.

Şirin G. (2007). Öğretmenlerin Duygusal Zeka Düzeyleriyle Stresle Başa Çıkma Tarzları Arasındaki İlişki. Yayınlanmamış Yüksek Lisans Tezi. Gazi Üniversitesi, Ankara 2007.

Özgün M. S. (2007). Okul Psikolojik Danışmanlarının Kişilik Özellikleri ile Mesleki Yetkinlik Beklentileri Arasındaki İlişkinin İncelenmesi. Yayınlanmamış Yüksek Lisans Tezi. Çukurova Üniversitesi, Sosyal Bilimler Enstitüsü, Adana 2007.

Tan H. (1992). Psikolojik Danışma ve Rehberlik. İstanbul 1992.

Ulusal Meslek Bilgi Sistemi (2012). Mesleğin Gerektirdiği Özellikler. Web: http:/e-ogrenme.iskur.gov.tr/ oyscontent/Courses/Course162/pdf/r/15.pdf (Erişim Tarihi: 01.12.2012)

Watson D. P. (1992). Counseling self-efficacy and counseling competence: A comparative study of clergy and counselors-in-training. http://proquest.umi.com/pqdlink?did=746982941\&Fmt=7\&clientId $=63518 \& R Q T=309 \& V N a m e=P Q D \& c f c=1$ Erişim Tarihi: 14. 03. 2013.

Weisinger, H. (1998). İş Yaşamında Duygusal Zeka. (1. Bask1). Çev. Nurettin Süleymangil. İstanbul 1998.

Yerli S. (2009). Illk ve Orta Öğretim Okullarındaki Yöneticilerin Duygusal Zeka ve Problem Çözme Becerileri Arasındaki İlişki. Yayınlanmamış Yüksek Lisans Tezi. Maltepe Üniversitesi, İstanbul 2009.

Yeşilyaprak B. (2001). “Duygusal zeka ve eğitim açısından doğurguları”. Kuram ve Uygulamada Eğitim Yönetimi 25 (2001) 139-146.

Yeşilyaprak B. (2013). Eğitimde Rehberlik Hizmetleri. Ankara 2013.

Yıldırım İ. (1992). "PDR programı öğrencileri ile psikoloji programı öğrencilerinin empatik eğilim ve empatik beceri düzeyleri”. Hacettepe Üniversitesi Ĕ̆itim Fakültesi Dergisi 7 (1992) 193-208.

Yiyit F. (2001). Okul Psikolojik Danışmanlarının Yetkinlik Beklentilerini Ölçmeye Yönelik Bir Ölçek Geliştirme Çalışması. Yayınlanmamış Yüksek Lisans Tezi, Çukurova Üniversitesi, Sosyal Bilimler Enstitüsü, Adana 2001. 